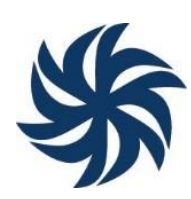

\title{
A CAPACIDADE DE ATUAÇÃO DA CÂMARA DOS DEPUTADOS NA POLÍTICA EXTERNA: ANÁLISE DOS INSTRUMENTOS DE ATUAÇÃO DA CÂMARA DOS DEPUTADOS NA POLÍTICA EXTERNA DE 1990 A 2017
}

\author{
THE CAPACITY OF EXPERTISE OF THE CHAMBER OF MEMBERS IN FOREIGN \\ POLICY: ANALYSIS OF THE INSTRUMENTS OF ACTION OF THE CHAMBER OF \\ DEPUTIES IN FOREIGN POLICY FROM 1990 TO 2017
}

\author{
LA CAPACIDAD DE EXPERIENCIA DE LA CÁMARA DE MIEMBROS EN \\ POLÍTICA EXTERIOR: ANÁLISIS DE LOS INSTRUMENTOS DE ACCIÓN DE LA \\ CÁMARA DE DIPUTADOS EN POLÍTICA EXTERIOR DE 1990 A 2017
}

Ulle Ráfaga Campos e Figueiredo ${ }^{1}$

\begin{abstract}
Resumo: Como a Câmara dos Deputados atua na Política Externa Brasileira dada a configuração institucional atual? O presente trabalho busca descrever os mecanismos que a Câmara dos Deputados detém para fazer política externa, além de detalhar como tais instrumentos têm sido utilizados. Para fins de análise, foi escolhido um recorte temporal de 1990 a 2017. Utilizando-se da metodologia descritiva e de estatísticas relativas às proposições apresentadas à Comissão de Relações Exteriores e Defesa Nacional da Câmara dos Deputados, pretende-se estabelecer quais dispositivos o órgão legislativo detém para atuar nesta matéria, bem como descrever como essa atuação tem transcorrido.
\end{abstract}

Palavra-chave: Legislativo; Política Externa; Câmara dos Deputados; Instrumentos.

Abstract: How does the Brazilian Chamber of Deputies act in Foreign Policy, given the present day institutional configuration? This paper aims to describe the mechanisms that the Chamber of Deputies holds for foreign policy, in addition to detailing how such instruments have been used. For the purposes of analysis, it was chosen to review cases from 1990 to 2017. Using the descriptive methodology and statistics related to the proposals presented to the Committee on Foreign Relations and National Defense of the Chamber of Deputies, it is intended to establish which provisions the legislative body holds to act in this matter, as well as describing how such action has occurred.

Keywords: Legislative; Foreign Policy; Chamber of Deputies; Instruments.

Resumen: ¿Cómo actúa la Cámara de Diputados en la Política Exterior brasileña dada la configuración institucional actual? Este documento busca describir los mecanismos que tiene la Cámara de Diputados para hacer política exterior, además de detallar cómo se han utilizado dichos instrumentos. Para fines de análisis, se eligió un marco temporal de 1990 a 2017. Utilizando la metodología descriptiva y las estadísticas relacionadas con las propuestas presentadas a la Comisión de Asuntos Exteriores y Defensa Nacional de la Cámara de Diputados, se pretende establecer qué disposiciones el cuerpo legislativo para actuar en este asunto, así como para describir cómo ha tenido esta actuación.

Palabras clave: Legislativo; Politica externa; Camara de los Diputados; Instrumentos.

\footnotetext{
${ }^{1}$ Mestranda em Ciência Política pela Universidade Federal de Pernambuco. Editora-executiva da Revista Política Hoje. E-mail: ullerafaga@ hotmail.com
} 


\section{Introdução}

Como a Câmara dos Deputados atua na Política Externa Brasileira dada a configuração institucional atual? Esse trabalho busca descrever os mecanismos que a Câmara dos Deputados detém para fazer política externa, além de detalhar como tais instrumentos têm sido utilizados. Para fins de análise, foi escolhido um recorte temporal de 1990 a 2017. O estudo se concentra neste período pelo fato do ano de 1990 ter sido o primeiro ano da Nova República em que a chefia do executivo, bem como toda a composição do legislativo, havia sido democraticamente eleita (NICOLAU, 2012). Considerando que uma das principais defesas de uma maior participação do Legislativo na política externa está relacionada à representatividade e ao controle da sociedade (LIMA; SANTOS; 2000), faz-se necessário que a análise passe por esse contexto de reestruturação na consolidação da democracia brasileira.

A Câmara dos Deputados não é um objeto tradicional de estudo quando se trata de política externa. A maioria dos trabalhos do tema, quando tratando do Legislativo, tende a considerar o Congresso como um todo, ou então dão ênfase ao Senado. De fato, a Comissão de Relações Exteriores do Senado possui mais competências que a Comissão de Relações Exteriores e Defesa Nacional da Câmara (SCHIMIDT, 2011). Ainda assim, diversos autores realizaram suas análises no entorno dela, inclusive fazendo menção à necessidade de se avaliar o comportamento legislativo na comissão da Câmara, sendo ela o primeiro órgão legislativo para o qual são enviados Atos Internacionais para aprovação. (DINIZ; RIBEIRO, 2008; DINIZ, 2009)

Existe uma lacuna a ser preenchida na literatura a respeito do tema, no que concerne a estudos específicos sobre a atuação da Câmara dos Deputados na política externa. Até recentemente, o insulamento burocrático do Itamaraty era consenso em matéria de política externa. Estudos mais recentes têm procurado evidenciar uma pluralização de atores na política externa brasileira (CASON; POWER, 2009). Houve um grande crescimento de artigos tratando da relação entre o Legislativo e o Executivo que procuram evidenciar o papel do Congresso Nacional na política externa brasileira (ALEXANDRE, 2006; FELIU; MIRANDA, 2011; FERREIRA, 2009; FIGUEIRA, 2009; MCDONNELL, 2016; MENDONÇA, 2012; NEVES, 2006; OLIVEIRA, 2013), mas tais estudos tratam apenas marginalmente da atuação da Câmara, criando espaço para trabalhos mais aprofundados sobre a capacidade de atuação da Casa. 
Assim sendo, o presente trabalho tem por objetivo realizar um esforço teórico para situar a Câmara nessa temática específica da política externa, enquanto tomador de decisão no ambiente doméstico.

Os argumentos descritivos aqui utilizados se enquadrarão no que Gerring (2010) tipifica como argumentos "indicadores", ou seja, são argumentos descritivos sobre os componentes unidimensionais de uma população, baseando-se na manifestação empírica de um fenômeno. Isso se dará porque a principal concentração deste trabalho será no sentido do uso dos instrumentos, observando-se sua frequência de utilização, assim como fizeram outros autores em metodologias que serão posteriormente explicadas (GERRING, 2010).

Os dados utilizados serão todos referentes a proposições analisadas pela Câmara dos Deputados no período de 1990 a 2017, que estão disponíveis para consulta no portal do órgão². Foi realizada uma análise quantitativa descritiva concentrando-se nos tipos de proposição passíveis de utilização para exercer influência na Política Externa.

Não serão levantadas novas hipóteses a respeito do uso dos instrumentos, valendo-se da crença de que a pesquisa em questão se enquadra no contexto de circunstâncias onde a verdade causal não tem limitações definidas, e, portanto, a inferência descritiva deveria ser realizada independentemente de qualquer hipótese causal particular. Do contrário, a descrição poderia se ver em ignorância de outras potencialidades causais. (GERRING, 2010)

O trabalho se dividirá em mais quatro seções. Na primeira seção trataremos da configuração institucional atual no que se refere à divisão e funcionamento dos poderes aqui tratados, com foco na atuação na política externa. Traremos os instrumentos citados pela literatura, com uma descrição a partir dos textos normativos e versaremos com mais detalhes sobre a Comissão de Relações Exteriores e Defesa Nacional - da Câmara dos Deputados -, órgão este responsável pela análise de todas as proposições relacionadas a Política Externa, além de tratar da tramitação geral de proposições na Câmara, com ênfase para as particularidades relacionadas à tramitação de atos internacionais.

2 Os dados estão disponíveis através do portal da Câmara dos Deputados através do link: http://www2.camara.leg.br/. Para fins de Replicabilidade informo que os dados foram retirados através da ferramenta de "Pesquisa Avançada", provida pelo próprio portal. 
Em seguida, iremos nos focar na literatura especializada no tratamento da Política Externa no Brasil, comentando o que era esperado considerando o debate acerca da globalização e da atuação de diferentes atores na Política Externa, para então definirmos, atualmente, quais são os consensos dos autores no tratamento da relação Legislativo-Executivo nesta matéria.

A terceira seção tratará mais especificamente das conclusões a que chegaram os autores proeminentes do estudo de processo decisório a respeito do uso de cada um destes instrumentos. Será realizada uma análise de dados quantitativos sobre a utilização destes instrumentos, a fim de verificar se as conclusões lançadas por estes autores ainda se fazem válidas até os dias de hoje.

Por fim, nas considerações finais deste trabalho mostraremos que as vertentes mais recentes do estudo dos diferentes atores da política externa são suportadas pelos dados apresentados, que mostram uma crescente atuação da Câmara dos Deputados, contrariando o senso comum de atuação mínima de aprovação formal dos Atos Internacionais.

\section{Da Configuração Institucional e os instrumentos para atuação na política externa}

\subsection{Da configuração institucional atual}

Sérgio Abranches (1988) coloca como as bases da tradição republicana do país: o presidencialismo, o federalismo, o bicameralismo, multipartidarismo e a representação proporcional. Dessa forma, o Brasil hoje adere a um regime federativo de presidencialismo de coalizão com o Legislativo bicameral em um sistema de multipartidarismo. Isso significa, inicialmente, que a União é formada pela junção dos estados, municípios e Distrito Federal, e que, no que concernem os três poderes ${ }^{3}$ que regem o país (Legislativo, Executivo e Judiciário), o Executivo é ocupado por um chefe de Estado, o Presidente, e o Legislativo é composto por duas casas (a Câmara dos Deputados e o Senado), ocupadas por Deputados Federais e Senadores, todos eleitos por meio da disputa entre diversos partidos (ABRANCHES, 1988; LIMONGI, 2006).

No bicameralismo, o Congresso Nacional se divide em duas casas, que contam com prerrogativas próprias para legislar. Tal como é praticado no Brasil, as regras de composição das duas casas são incongruentes entre si as atribuições políticas são distribuídas simetricamente entre elas, o que leva à existência de dois veto players ${ }^{4}$ institucionais. (ARAÚJO, 2014).

$\mathrm{Na}$ divisão do governo em três poderes entende-se geralmente que os poderes se dividem pelas funções que exercem. A luta constante entre os poderes garante a preservação de uma separação entre os três e a manutenção severa de todos eles, a fim de evitar que a tirania se implante no mundo, com o predomínio de um poder e, dentro desse poder, o predomínio de um

\footnotetext{
${ }^{3}$ Não é relevante para a organização deste trabalho que se discuta a composição do Judiciário, de modo que esse assunto não será abordado.

${ }^{4}$ Veto Players são atores cuja concordância é requerida para tomar a decisão de mudar uma política. (TSEBELIS, 1995).
} 
homem. Assim, as concepções que se baseiam nessa argumentação concluem que em sistemas presidencialistas a divisão entres poderes deve funcionar como mecanismo de pesos e contrapesos a fim de garantir o controle democrático no sistema. Daí a importância do estudo da dinâmica existente entre eles na atuação na política externa. (BALEEIRO; BRITO; CAVALCANTI, 2012; FIGUEIRA, 2009)

No Legislativo, a Câmara dos Deputados tem o papel atribuído de (1) autorizar a instauração de processo contra o Presidente e o Vice-Presidente da República e os Ministros de Estado; (2) proceder à tomada de contas do Presidente da República, quando cabível; (3) elaborar seu regimento interno; (4) dispor sobre sua organização, funcionamento, polícia, criação, transformação ou extinção de cargos, empregos e funções de seus serviços; e a iniciativa de lei para fixação respectiva da remuneração; além de (5) eleger membros do Conselho da República, nos termos do art. 89, VII da Constituição Federal.

Como pode ser observado, o texto constitucional atual não trata da Câmara como um ator com protagonismo na política externa. Ocorre que, na redemocratização, o contexto era da presença de uma nova ordem internacional progressivamente institucionalizada a partir dos conflitos sociais que marcaram o século. Assim, fazia-se presente uma exacerbação do nacionalismo, com a defesa da soberania e do princípio de autodeterminação dos povos, contrastando com o intercâmbio entre as nações, que vinha desenvolvendo um sistema crescente de maior convivência internacional e regional. Nesse contexto, a estratégia da Constituição de 1988 foi garantir ao Executivo o controle sobre as políticas e as instituições brasileiras, que contavam com instrumentos constitucionais e regimentais que favoreciam sua predominância decisória, desfavorecendo a accountability horizontal. (FIGUEIRA, 2009; TÁCITO, 2012)

Se observadas as temáticas já preditas na Constituição como de competência do Congresso, fica ausente, conforme o Artigo 48, o tratamento de temáticas relacionadas diretamente aos interesses brasileiros no âmbito internacional.

É colocado, no Artigo 49 da Constituição, que é de competência exclusiva do Congresso Nacional resolver definitivamente sobre tratados, acordos ou atos internacionais que acarretem encargos ou compromissos gravosos ao patrimônio nacional, além de autorizar o Presidente da República a declarar guerra, a celebrar a paz, a permitir que forças estrangeiras transitem pelo território nacional ou nele permaneçam temporariamente, ressalvados os casos previstos em lei complementar. 
A expressão"[...]que acarretem encargos ou compromissos gravosos ao patrimônio nacional" (Art.49, Inciso I da Constituição Federal de 1988) gerava dualidade, no sentido da interpretação permitir considerar que certos tipos de acordos que não se enquadrassem nessa classificação não necessitassem do crivo do Legislativo. Da mesma forma, fez-se ausente na regulamentação das atribuições tanto do Poder Executivo quanto do Poder Legislativo a menção do termo "ajustes" nos atos quando na tramitação dos Atos Internacionais. Essa possível "flexibilidade" de interpretações inclusive pode se relacionar a tentativas ${ }^{5}$ por parte dos Deputados de inserir Emendas à Constituição que mudassem o processo decisório em matéria de política externa.

Atualmente, a atuação formal da Câmara dos Deputados na política externa é exercida através dos mecanismos presentes em seu Regimento Interno, dos quais trataremos a seguir.

\subsection{Dos instrumentos de atuação na política externa}

\subsubsection{Da tramitação de proposições na Câmara e a CREDN}

Nesta seção nos concentraremos na descrição dos instrumentos considerados em nossa análise. A seleção dos instrumentos foi realizada em consideração com a literatura especializada, bem como algumas adições feitas baseadas no estudo do Regimento Interno da Câmara dos Deputados e da Constituição Federal. Todas as descrições aqui feitas serão de acordo com informações oficiais da Câmara, disponibilizadas em seu Regimento Interno e seu Portal na internet.

Toda matéria sujeita à deliberação da Câmara dos Deputados é tratada como proposição. As proposições podem ser propostas de emenda à Constituição - PEC's, projetos (Projetos de Lei PL, Projetos de Lei Complementar - PLP, Projetos de Lei de Conversão - PLV, Projeto de Decreto Legislativo - PDC e Projetos de Resolução - PRC), emendas, indicações - INC, requerimentos - REQ, recursos, pareceres ou ainda propostas de fiscalização e controle. (Cap. 1, Art.100 do Regimento da Câmara dos Deputados)

Dentre as proposições, serão considerados como instrumentos para atuação na política externa os: (1) Projetos de Lei - aqui incluindo também os Projetos de Lei Complementar, (2) Requerimentos e Indicações, (3) Projetos de Decreto Legislativo - pelos quais são apreciados os Ato Internacionais, enviados à Câmara dos Deputados por meio de Mensagens Presidenciais MSC, e (4) Projetos de Emenda Constitucionais que tratam especificamente de mudanças no padrão decisório em matéria de política externa.

Cada proposição, salvo emenda, recurso ou parecer, tem curso próprio na tramitação dentro

\footnotetext{
${ }^{5}$ Dentro do período estudado por este trabalho foram identificadas proposições propostas por membros da Câmara dos Deputados que visavam alterar o padrão decisório em matéria de política externa, inclusive atribuindo maior possibilidade de atuação ex-ante por parte dos Deputados Federais. Destacam-se: PEC 31/2003 Deputado Ney Lopes (PFL-RN); PEC 70/2003 Deputado Devanir Ribeiro (PT-SP); PEC 389/2005 Deputado João Alfredo (PT-CE); PL 4938/1990 Deputado Gerson Marcondes (PMDB-SP)
} 
da Câmara dos Deputados. De modo geral, primeiramente, tem-se a apresentação da proposição à Mesa Diretora. A proposição é então despachada pela Secretaria-Geral da Mesa, às comissões competentes. Na comissão, a proposição recebe um relator, que dá seu parecer sobre a matéria. (Art. 24, op.cit; Portal da Câmara dos Deputados)

Comissões permanentes, como a Comissão de Relações Exteriores e Defesa Nacional CREDN, têm, com algumas exceções, a competência de discutir e já votar Projetos de Lei, dispensada a competência do Plenário. Caso a matéria ainda tenha que ser analisada em Plenário, ela é encaminhada ao relator, sem fase de emendas. Supondo-se que haja emendas, o relator então analisa o texto e apresenta seu relatório e volto. (Art. 24, op.cit; Portal da Câmara dos Deputados)

Figura 1 - Fluxograma de Tramitação Ordinária na Câmara dos Deputados

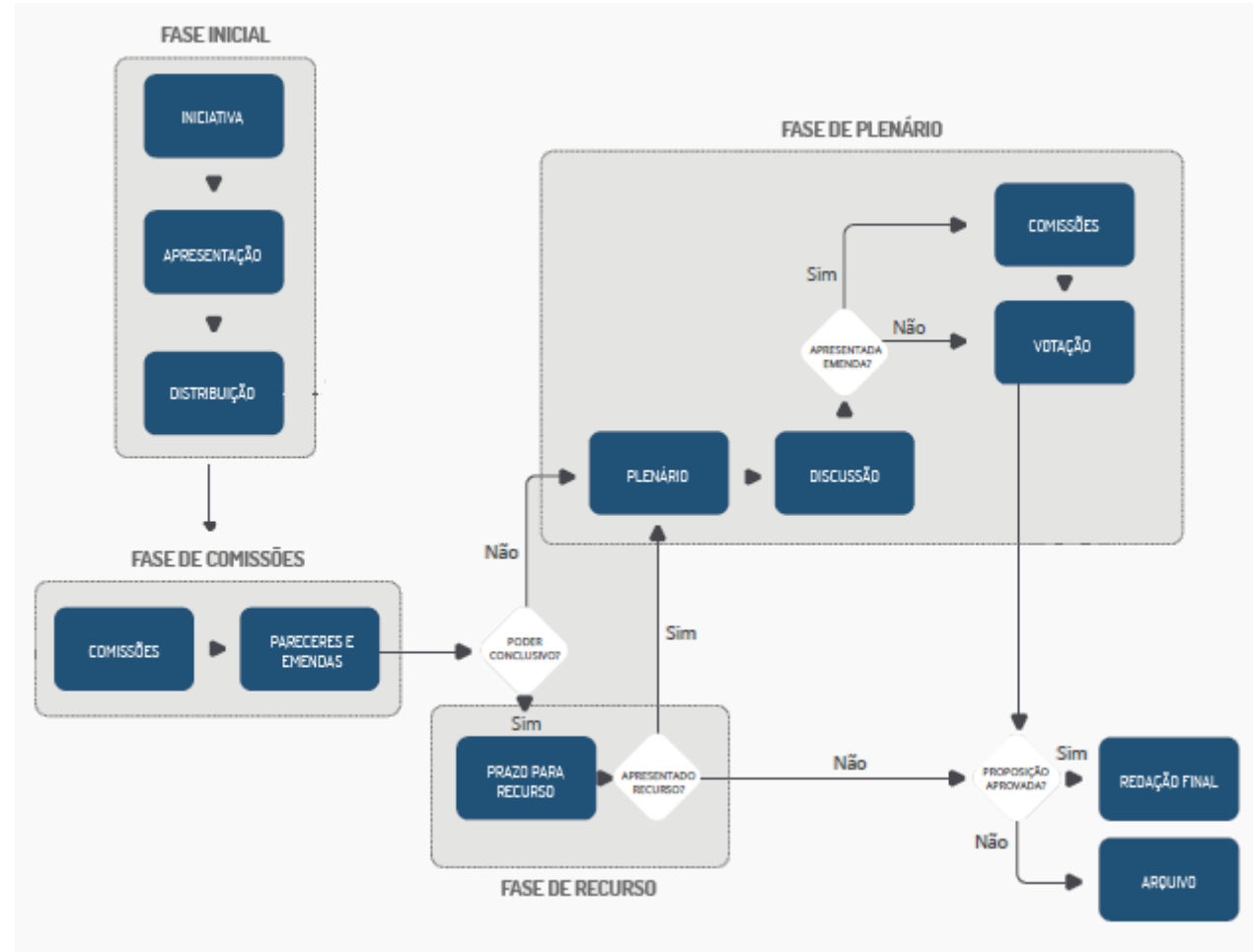

Fonte: Escola Virtual de Cidadania. Câmara dos Deputados. Adaptado. Disponível em: $<$ https://escolavirtualdecidadania.camara.leg.br/site/wp-content/uploads/2016/11/fluxograma-detramitacao-ordinaria.pdf $>$. Acesso em 21 de fevereiro de 2018.

Pode-se propor a aprovação total ou parcial da proposição, a rejeição, apresentação de emendas, o arquivamento, ou apresentar um projeto substitutivo, totalmente alternativo, porém nesse caso é preciso abrir prazo para emendas. Após a discussão da matéria das comissões dá-se uma votação. A proposição com parecer aprovado segue para a comissão seguinte. Se não for uma matéria com tramitação conclusiva, e que já tenha sido apreciada pela Comissão de Constituição, Justiça e de Cidadania - CCJ, ela segue para o plenário. (Art. 24, op.cit; Portal da 
Câmara dos Deputados).

No caso dos Atos Internacionais a tramitação tem suas particularidades. Primeiramente, o Ato é enviado à Câmara por meio de Mensagem Presidencial, que contém todo o teor do tratado, acompanhado dos motivos apresentados pelo MRE. A Mensagem é então distribuída às Comissões pertinentes. A matéria tratada é então apresentada como Projeto de Decreto Legislativo. Aprovada, ela segue para o Plenário.

Figura 2 - Fluxograma de Tramitação de Atos Internacionais no Legislativo

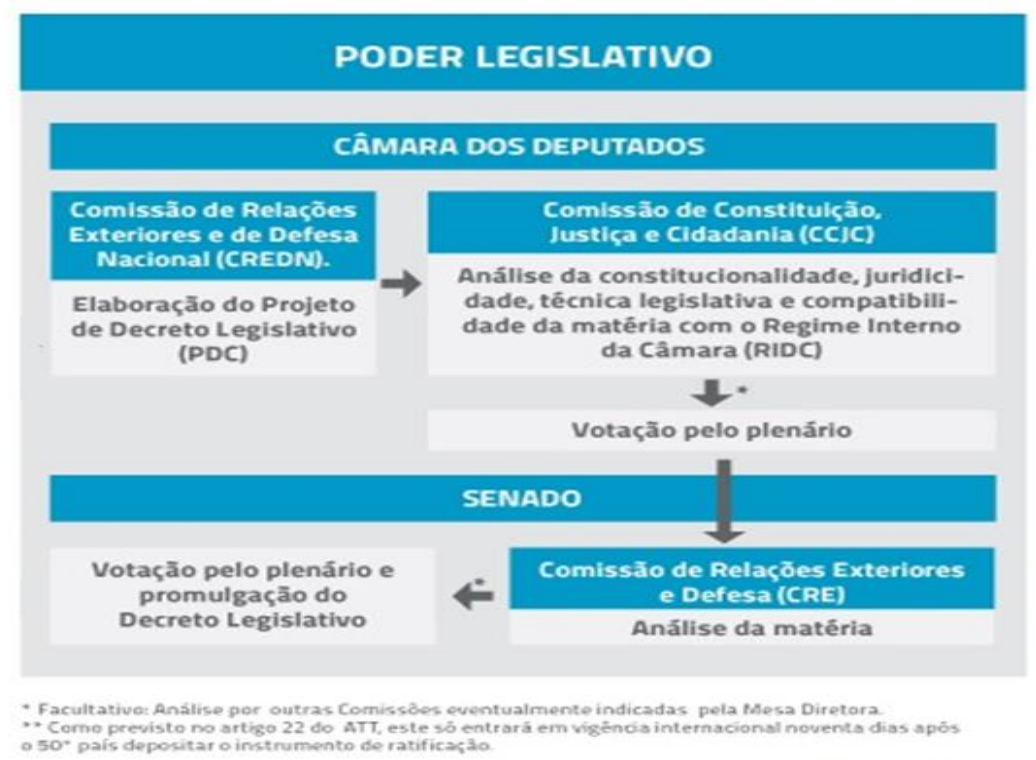

Fonte: Instituto Sou da Paz. Arms Trade Treaty. Adaptado. Disponível em: <http://www.soudapaz.org/o-quefazemos/documento/arms-trade-treaty-1>. Acesso em 21 de fevereiro de 2018.

A CREDN é uma Comissão Permanente, instituída pela Resolução datada de 15 de setembro de 1936, com a denominação de "Diplomacia e Tratados". Após algumas mudanças, ela passou a ser chamada pelo nome atual pela Resolução $n^{0}$ 15, de 1996, art. 32, inciso XV do atual Regimento Interno da Câmara dos Deputados.

São de sua competência: (a) relações diplomáticas e consulares, econômicas e comerciais, culturais e científicas com outros países; relações com entidades internacionais multilaterais e regionais; (b) política externa brasileira; serviço exterior brasileiro; (c) tratados, atos, acordos e convênios internacionais e demais instrumentos de política externa; (d) direito internacional público e privado; ordem jurídica internacional; nacionalidade; cidadania e naturalização; regime jurídico dos estrangeiros; emigração e imigração; (e) autorização para o Presidente ou o Vice-Presidente da República ausentar-se do território nacional; (f) política de defesa nacional; estudos estratégicos e atividades de informação e contrainformação; (g) Forças Armadas e Auxiliares; administração pública militar; serviço militar e prestação civil alternativa; passagem de forças estrangeiras e sua permanência no território nacional; envio de tropas para o exterior; 
(h) assuntos atinentes à faixa de fronteira e áreas consideradas indispensáveis à defesa nacional; (i) direito militar e legislação de defesa nacional; direito marítimo, aeronáutico e espacial; (j) litígios internacionais; declaração de guerra; condições de armistício ou de paz; requisições civis e militares em caso de iminente perigo e em tempo de guerra; $\left(\mathrm{m}^{6}\right)$ outros assuntos pertinentes ao seu campo temático. (Art. 32, op.cit; Portal da Câmara dos Deputados ${ }^{7}$ ).

\subsubsection{Dos projetos de lei}

Projetos de lei destinam-se a regular as matérias de competência do Poder Legislativo, com a sanção da Presidência da República. Existem, além de Projetos de Lei Ordinária, Projetos de Lei Complementar, que tratam de matérias específicas definidas pela Constituição Federal, e necessitam da maioria absoluta para serem aprovados pela Casa, além de necessitarem de dois turnos de apreciação. Na análise aqui realizada ambas foram consideradas conjuntamente, em "Projetos de Lei". No que diz respeito à política externa, por exemplo, Projetos de Lei Complementares tratam, entre outros assuntos do trânsito de forças estrangeiras em território nacional, como definido pelo artigo 21, IV da Constituição Federal. Tais projetos de lei podem ser utilizados para atuação na política externa ao abordarem temas de agenda soft, como aqueles relativos a concessão de visto para estrangeiros (PL 975/2015, que acrescenta o art. 15-A na Lei $n^{\circ} 6.815$, de 19 de agosto de 1980, estabelecendo critérios para a concessão de visto temporário e autorização de trabalho nos casos que especifica.), o registro de estrangeiros no país (PL 1664/2007 que amplia, para o estrangeiro em situação ilegal no território nacional, o prazo para requerer registro provisório), e até temas mais complexos, como a PL 7115/2014, que assegura a proteção dos interesses das empresas brasileiras e suas controladas, que atuam no exterior, contra medidas restritivas ou arbitrárias dos Estados nos quais realizam as suas atividades. (BRASIL, 2014, art. 108; PACHECO, 2015).

\subsubsection{Dos projetos de decreto legislativo}

Projetos de Decreto Legislativo são aqueles que regulam as matérias de exclusiva competência do Poder Legislativo, sem sanção da Presidência. É através deles que se dá a apreciação dos tratados internacionais, enviados à Câmara dos Deputados por meio de Mensagens Presidenciais, e podem ser apresentados por qualquer Deputado ou Comissão. Além dos Projetos referentes a Mensagens Presidenciais para apreciação dos tratados têm-se ainda aqueles de própria autoria dos Deputados, como o PDC 11/2007, que estabelece diretrizes para a negociação de atos internacionais que regulem as obrigações brasileiras para redução de

\footnotetext{
${ }^{6}$ Foi reproduzido o mesmo sequenciamento utilizado no Regimento Interno da Câmara. A Resolução no 20 de 2004 saltou a letra "l" no sequenciamento deste inciso.

7 Histórico e Atribuições. Comissão de Relações Exteriores e Defesa Nacional. Disponível em: $<$ http://www2.camara.leg.br/atividade-legislativa/comissoes/comissoes-permanentes/credn/conheca-acomissao/index.html> Acesso em 21 de fevereiro de 2018.
} 
emissões de gases de efeito estufa e as ações cooperativas para enfrentar mudanças climáticas globais decorrentes da elevação da temperatura média no planeta (BRASIL, 2014, art.108)

\subsubsection{Dos requerimentos e indicações}

Requerimentos são proposições destinadas a formalizar solicitações dos Deputados Federais. Eles viabilizam maior busca de informações por parte dos Deputados e uma maior participação nas temáticas lideradas pelo Executivo. Já indicações são as proposições através das quais os congressistas sugerem a outro Poder a adoção de providência, a realização de ato administrativo ou de gestão, ou o envio de projeto sobre a matéria de sua iniciativa exclusivo, assim como sugerem a manifestação de uma ou mais Comissões acerca de determinado assunto, visando a elaboração de projeto sobre matéria de iniciativa da Câmara. Elas podem servir para atuação na política externa no sentido de trazer sugestões sobre determinadas ações dentro da diplomacia, como a INC 4865/2005 que sugeria que o MRE exigisse retratação do Senhor Pascoal Lamy, referente a afirmações dele de que a Amazônia e outras florestas tropicais fossem consideradas bens públicos mundiais e submetidas à gestão coletiva ou gestão de comunidade internacional (BRASIL, 2014, art. 113 e 114; FIGUEIRA, 2009; PACHECO, 2015).

\subsubsection{Das Pec's de mudança no processo decisório}

Propostas de Emenda à Constituição são proposições que têm o intuito de promover alterações no texto constitucional. Por meio deles, como já foi proposto, os Deputados podem realizar tentativas de alteração no processo decisório relativo à política externa, atribuindo maior nível de consulta formal ao Legislativo ainda na etapa ex ante do processo. (FIGUEIRA, 2009).

\subsubsection{Da Secretaria de Relações Internacionais da Câmara Dos Deputados}

É importante notar, ainda, que a Câmara dos Deputados tem uma secretaria específica para relações internacionais, com a atividade inclusa no Regimento Interno da Câmara. Criada em 2015, ela tem o objetivo de ampliar o alcance das atividades de diplomacia e cooperação parlamentar, que já eram desenvolvidas na instituição. É de sua responsabilidade o estabelecimento das diretrizes da diplomacia parlamentar na Câmara, além de promover a cooperação com parlamentos de Estados estrangeiros e apoiar delegações, comitivas e representações de deputados em missão oficial (RICD, art.21).

Ela não é objeto de estudo da literatura especializada, o que provavelmente se deve à sua criação recente, de modo que não serão inclusos na análise do uso dos instrumentos dados relativos à sua atividade, mas ainda assim não se pode ignorar presença de um órgão como esse enquanto indicativo de um ensejo, real, de atuação na política externa. 


\section{Da literatura sobre a relação Executivo-Legislativo no tratamento da política externa}

A literatura apresenta diversos argumentos para colocar que o esperado, no contexto da globalização e da cada vez mais intensa interação entre os países, de que houvesse um maior envolvimento do Congresso Nacional em matérias de Política Externa. Destacam-se nesse quesito as considerações de Martin (2000), Lima (2001), Figueira (2009) e Galdino, Oliveira e Ribeiro (2009).

Martin (2000) coloca que a política internacional e a política doméstica não são "criaturas" que habitam universos diferentes, mas sim campos aos quais podem-se aplicar modelos e conceitos semelhantes. Ela trabalha com os compromissos do Estado e sua credibilidade, operando sob a premissa de que a participação de um Legislativo organizado tem um efeito positivo sobre as relações internacionais, dando credibilidade ao Estado em questão. Isso ocorreria por que a participação do Legislativo seria um indicativo de que as decisões tomadas teriam sido fruto de um debate doméstico que teria passado pelas devidas instâncias democráticas, que, portanto, levaria a decisões mais estáveis e assim mais críveis. (MARTIN, 2000).

Especificamente no caso Brasileiro, Lima e Santos (2001) colocam que havia uma congruência inerente nas preferências do Legislativo e do Executivo no pós-guerra, como visto nos esforços para a industrialização no período. Assim, fazia sentido que houvesse uma delegação de tarefas ao executivo que mantinha seu papel aparentemente menor no que tangia as matérias de Política Externa. Esse quadro perdurou até quando ocorreu o exemplo emblemático da de congruência entre os poderes, que eram a política tarifária e a relutância do país de abrir sua economia para importações, deixassem de servir ao objetivo da industrialização. Ocorreu então distanciamento entre Executivo e Legislativo no âmbito da política de comércio exterior, que só aumentou com a superinflação. A antiga delegação congressual para que o Executivo definisse os objetivos da ação governamental, e a centralização das decisões no Executivo, juntamente com o insulamento do Itamaraty, teve como efeito mais visível a falta de controle democrático sobre as decisões governamentais no âmbito da política de comércio exterior. (MARTIN, 2000; LIMA \& SANTOS, 2001; FIGUEIRA, 2009; GALDINO, OLIVEIRA \& RIBEIRO, 2009).

O profissionalismo, as capacidades de negociação do Itamaraty e a sua relativa autonomia nas agendas da política externa brasileira a mantiveram, até recentemente, relativamente imune a mudanças e ingerências das agendas governamentais (MILANI \& PINHEIRO, 2013).

Há uma crítica constante feita ao insulamento do Ministério das Relações Exteriores na política externa, sendo considerada por seus críticos até mesmo como um monopólio (op.cit., 2012), mas vem se criando um consenso a respeito da participação de outras entidades na política externa, além do aumento da atuação de algumas, como é o caso do Congresso 
Nacional.

O tema da diversificação dos atores relevantes à política externa começou a mostrar maior relevância nos anos 1990, com a publicação de diversos estudos na área. Diversos autores consideraram a responsabilidade acadêmica de considerar a interação dos demais atores no processo, dada a complexidade da dinâmica em questão. Assim, a atual presença do processo decisório, da diversidade temática e da dinâmica política nas agendas de estudo permitem ao pesquisador explorar relações mais complexas no que tange à política externa.

Milani e Pinheiro (2013) colocam que apesar do fato recorrente no estudo da disciplina de atribuir a um único indivíduo ou a uma única instituição a origem das decisões da política externa, supor que a presença de lideranças carismáticas ou o monopólio de uma agencia possam sozinhas explicar a definição dos interesses do país no plano internacional se tornou analiticamente menos convincente. Para os autores, a Política Externa precisa de parâmetros de investigação que incorporem os diversos atores presentes no seu processo decisório, em suas mais distintas formas de participação e levando-se em conta os variados modelos de interação política.

No que consta o tratamento de outros atores que não o Executivo, o senso comum, quando se tratando da relação entre Legislativo e Executivo na política externa é de que o Congresso serve apenas como uma formalidade de chancela automática dos tratados assinados pelo Executivo. É importante notar que em nossa história republicana poucas vezes os parlamentares rejeitaram a aprovação de um acordo internacional encaminhado pelo Executivo. Oliveira (2004) sustentava "a nulidade de atuação dos atores políticos e do Legislativo brasileiro", atribuindo esse comportamento ao baixo rendimento eleitoral de temas de política externa. (ALEXANDRE, 2006; OLIVEIRA, 2004).

De maneira geral, apesar de existir espaço para uma discussão valorativa a respeito do modelo ideal de atuação em política externa em termos da participação e do equilíbrio entre os poderes, primeiramente se faria necessário chegar a uma conclusão final sobre o principal debate hoje em dia, se o senso comum da baixa participação do Legislativo estaria, de fato, correto.

Os argumentos nessa área se dividem em diferentes posicionamentos sobre dois objetos diferentes. Primeiramente, temos a consideração sobre a atuação do Legislativo no geral, depois, mais especificamente, têm-se posicionamentos a respeito da baixa taxa de rejeição dos atos internacionais por parte do Congresso.

No primeiro objeto, tem-se uma linha da literatura que comenta sobre um baixo interesse das Casas, devido à especificidade do tema, que demanda um know-how especializado e ao baixo retorno político associado ao envolvimento com a política externa. Assim sendo, o poder de influência do Congresso no processo decisório da política externa fica limitado à aprovação $e x$ post de acordos ou tratados internacionais, além da participação dos membros do Congresso em 
Comissões Parlamentares que tratem da política externa. (ALEXANDRE, 2006; FIGUEIRA,2009; MENDONÇA, 2012).

A função utilidade dos congressistas é a busca pela reeleição, o que indica que eles adotarão medidas que contribuam para este objetivo. Assim sendo, congressistas participariam de Comissões Parlamentares que expressassem de maneira mais direta o interesse de seu eleitorado. Como matérias de política externa seriam consideradas de baixa prioridade pelo grande público, não haveria retorno que justificasse o envolvimento. É importante lembrar, porém, que essa perspectiva considera a política externa como majoritariamente pertencente à agenda hard, ou seja, que evoca características sensíveis na relação dos Estados, afastando-se da diplomacia pública e entrando na área da diplomacia secreta. Essa abordagem, amplamente difundida na literatura, não enaltece os itens da agenda soft, que lida com o aspecto distributivo de temáticas mais próximas ao cotidiano dos cidadãos (ALEXANDRE, 2012; FIGUEIRA, 2009; LIMONGI, 2002).

Além disso, essa perspectiva, foca muito mais nos instrumentos formais e de influência direta cabíveis ao Legislativo - e nesse caso diretamente aplicado ao nosso objeto de estudo à Câmara dos Deputados. Apesar de não desconsiderarem totalmente instrumentos informais - ou pelo menos não institucionalizados formalmente para utilização como tal - e de influência indireta, o principal foco desta perspectiva é na apreciação ex post dos Tratados Internacionais.

Para eles, então, a Câmara teria uma influência quase mínima em termos de possibilidade de atuação, justificada pelo desinteresse dos Deputados em atuar numa temática sem retorno eleitoral, além da própria estrutura decisional em política externa, que favorece o Executivo.

Quanto ao segundo objeto, do baixo ${ }^{8}$ índice de rejeição das propostas do Executivo, essa perspectiva considera que se trata de um sinal de inércia, ou não atuação. Diniz (2009) inclusive levanta a possibilidade de que a Câmara não agisse de fato como um veto player, dada a baixíssima taxa de rejeição.

Do outro lado da moeda temos autores que consideram que existe, sim, influência do Legislativo na Política Externa, mesmo que não seja formalmente institucionalizada. Tais atores estão mais abertos à consideração de instrumentos informais, como por exemplo o atraso deliberado na avaliação de proposições de atos internacionais do Executivo, bem como da influência indireta, exercida pela mera existência da Câmara como veto player, que poderia contribuir para a congruência das preferências dos poderes ou mesmo fazer com que o próprio Executivo alterasse seu comportamento diante da possibilidade de veto, que portanto faria a opção de considerar as preferências da Câmara ao negociar o ato internacional ou mesmo simplesmente não propor algo que não seria aceito pela Câmara. (DINIZ, 2009; FIORINA,1982; LINDSAY; 1993; MARTIN, 2000; MCCUBBINS; NOLL; WEINGAST,

\footnotetext{
${ }^{8}$ DINIZ; RIBEIRO (2008); e DINIZ (2009) realizaram análises quanto às Mensagens Presidenciais enviadas à Câmara dos Deputados entre 1988 e 2006, encontrando apenas 3 casos de rejeição explícita.
} 
1987; WEINGAST, 1984)

Nessa perspectiva de avaliação, que admite um olhar mais flexível sobre a atuação, Martin (2000) defende de forma veemente que a participação do Legislativo não poderia ter como instrumento de mensuração somente os mecanismos institucionalizados, devendo-se levar em conta a antecipação de preferências que ocorre de ambos os lados. Lindsay (1993) e Weingast (1984) apresentam argumentos que complementam essa lógica, ao tratar das "reações antecipadas", onde a possível atuação do Legislativo como veto player forçaria o executivo a considerar suas preferências ex ante. Nas palavras de Lindsay:

[...] em qualquer arranjo institucional estável as pessoas reagirão estrategicamente. Assim como em jogos de xadrez consideram os possíveis movimentos de seus oponentes e planejam vários passos afrente, o Congresso e o Executivo anteciparão o comportamento um do outro e modificarão seu próprio comportamento de acordo. Presidentes são especialmente propensos a antecipar o humor do Congresso na política externa, por que rejeições públicas ameaçam enfraquecer sua credibilidade no cenário mundial (LINDSAY, 1993).

Diniz (2009) inclusive utiliza essa argumentação diretamente com a Câmara em seu artigo "Atos internacionais e atuação do legislativo", no qual ela conclui que embora os dispositivos da Constituição brasileira deixem pouco espaço para manobra dos Deputados em termos de atuação direta, ela encontrou, sim, indicativos de uma influência indireta da Câmara nas questões de política externa, conforme destacado por Lindsay (1993).

\section{Do uso dos instrumentos de atuação}

\subsection{Da análise}

Os instrumentos aqui analisados foram escolhidos com referência em nas obras de Figueira (2009), Diniz; Ribeiro (2008) e Diniz (2009). Figueira faz um estudo do processo decisório em política externa no Brasil onde ela considera o equilíbrio de poder na dinâmica do Itamaraty e do Legislativo enquanto atores da política externa. Do lado do Legislativo, ela foca a análise em PEC's de mudança no processo decisório de acordos internacionais, Projetos de Lei, Requerimentos e Indicações tanto na Câmara dos Deputados quanto no Senado Federal. Já os trabalhos de Diniz e Ribeiro se focaram na tramitação de atos internacionais, feita na Câmara dos Deputados através de Projetos de Decreto Legislativo. É importante notar que Diniz e Ribeiro já focam a análise diretamente na Câmara dos Deputados, sendo alguns dos poucos autores a fazer isso.

Os dados utilizados foram da tramitação de proposições relativas aos instrumentos na CREDN, e foram fornecidos pela própria Câmara dos Deputados, através de demanda do sistema de dados abertos, e complementações foram feitas pela ferramenta de pesquisa avançada do portal, de modo que todos os dados aqui utilizados estão disponíveis à consulta de modo livre. A organização dos dados para a análise foi feita de modo a replicar o método 
aplicado por Figueira (2009), no qual ela analisa a tramitação das proposições entre os anos de 1988 a 2006. No que condiz às variáveis, ela se foca apenas os aspectos quantitativo e temporal. Neste trabalho acrescentamos à análise o aspecto da autoria da proposição, dividida nas matérias apresentadas por Deputados, pelo Executivo, e por outros.

Como observado, as bases deste trabalho foram os artigos publicados por Diniz e Ribeiro, bem como a obra de Figueira.

No artigo de 2008, "The role of the Brazilian congress in foreign policy: an impirical contribution to the debate", Diniz e Ribeiro utilizam nas Mensagens Presidenciais referentes a acordos internacionais enviadas à Câmara dos Deputados entre 1988 e 2006. Operando sob a perspectiva de que o modelo institucional brasileiro não restrinja totalmente o processo decisório da política externa, eles realizam uma análise quantitativa nas Mensagens, tramitadas como Projetos de Decreto Legislativo, além de uma análise qualitativa nas propostas que não foram aprovadas. Ao final, eles consideram que é possível identificar a existência de uma participação mais ampla do que a maior parte da literatura comenta.

No artigo publicado em 2009, "Atos Internacionais e Atuação do Legislativo", Diniz aprofunda o debate teórico ao acrescentar a perspectiva de Lindsay sobre possibilidades de ação indireta, tanto na influência exercida pela mera existência da Câmara como veto player, quanto pela probabilidade de haverem discussões informais ex ante. Ela utiliza a mesma metodologia do artigo de 2008, e acrescenta às conclusões que mesmo que os dispositivos da Constituição deixem pouco espaço para uma atuação direta dos parlamentares na deliberação dos tratados, é possível encontrar indicações de influência do Legislativo nas questões externas.

Apesar da análise aqui feita dos Projetos de Decreto Legislativo não incluir a metodologia qualitativa, muito bem aplicada na ocasião, iremos incluir Projetos de autoria própria dos Deputados, além de projetos de outras autorias, que não foram consideradas pelos autores.

Já Figueira, em sua tese de doutorado defendida em 2009, "Processo Decisório em Política Externa no Brasil" busca compreender o padrão e a dinâmica decisória na matéria em um período de redemocratização, de 1988 a 2007. Ela conclui que houve uma crescente participação do Poder Legislativo na política externa, embora tímida, e que apesar das tentativas de alteração do padrão decisório, o processo de tomada de decisão continua centrado significantemente nas "mãos" do Executivo.

É importante notar que, apesar deste trabalho utilizar aspectos metodológicos destes autores, há diferenças no tratamento dos dados. Primeiramente, Figueira não fala explicitamente que as propostas foram escolhidas para análise passaram pela CREDN, embora essa seja a tramitação esperada de acordo com as normas. Diniz e Ribeiro, por sua vez, apesar de incluírem todos os casos relativos a Mensagens Presidenciais, realizaram uma análise diferenciada baseada no resultado final da deliberação dos atos.

Para fins de uniformização do tratamento, nesta análise foram considerados todos os casos 
que tramitaram na CREDN, desconsiderando-se a aprovação ou não aprovação das proposições, já que o uso do instrumento foi realizado independentemente do efeito produzido.

Foram excluídas da análise proposições que tivessem passado pela CREDN, mas que não tratassem de matéria de política externa, relações internacionais, direito internacional, e/ou qualquer temática relacionada aos temas acima citados. Finalmente, o ano de cada proposta da análise foi o ano em que proposição foi apresentada, e não o ano em que a proposta foi analisada pela Comissão de Relações Exteriores.

Quadro 1 - Literatura do Uso dos Instrumentos de Atuação em Política Externa

\begin{tabular}{|l|l|l|l|}
\hline Instrumento & Quem Aborda & Período Analisado & Conclusões \\
\hline Projetos de Lei & Figueira (2009) & 1988 a 2007 & $\begin{array}{l}\text { Tendência de alta no decorrer dos } \\
\text { anos, porém poucos casos. }\end{array}$ \\
\hline $\begin{array}{l}\text { Projetos de } \\
\text { Decreto } \\
\text { Legislativo }\end{array}$ & $\begin{array}{l}\text { Diniz \& Ribeiro } \\
\text { (2008) Diniz } \\
(2009)\end{array}$ & 1988 a 2006 & $\begin{array}{l}\text { Pouca possibilidade de influência } \\
\text { formal. Desejo crescente dos } \\
\text { Deputados de atuar na política } \\
\text { externa. }\end{array}$ \\
\hline $\begin{array}{l}\text { Requerimentos e } \\
\text { Indicações }\end{array}$ & Figueira (2009) & 1988 a 2007 & $\begin{array}{l}\text { Instrumentos mais utilizados. Eles } \\
\text { não têm a mesma força normativa } \\
\text { que PL's e PDC's. }\end{array}$ \\
\hline $\begin{array}{l}\text { PEC's de } \\
\text { Mudança no } \\
\text { Processo } \\
\text { Decisório }\end{array}$ & Figueira (2009) & 1988 a 2007 & $\begin{array}{l}\text { No geral, os parlamentares buscam } \\
\text { adotar como referência o atual } \\
\text { modelo norte-americano, onde o } \\
\text { Congresso tem forte papel no } \\
\text { sentido de contrabalancear o } \\
\text { Executivo. }\end{array}$ \\
\hline
\end{tabular}

Fonte: Elaboração própria, 2020. 


\subsection{Do uso dos projetos de lei}

Gráfico 1 - Proposições de Projetos de Lei Apreciadas pela CREDN de 1990 a 2017

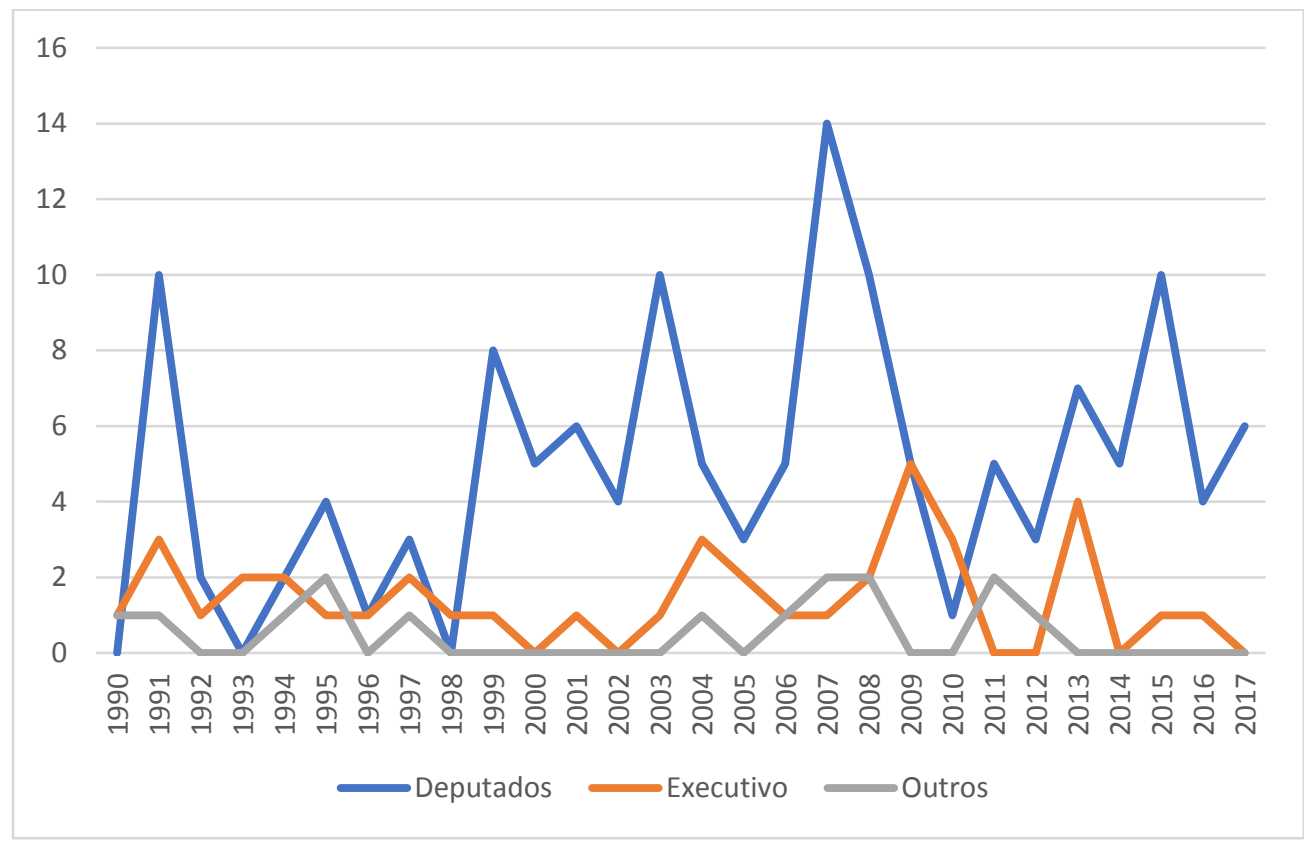

Fonte: Dados compilados pela autora a partir do portal da Câmara dos Deputados, 2019.

Figueira (2009), ao analisar os Projetos de Lei aprovados pela CREDN até o ano de 2007, observou poucos casos, embora como uma tendência de alta. Apesar de uma baixa no ano de 2010, essa tendência mostra-se presente ainda nos dias de hoje. Dos 193 casos analisados, 89 foram arquivados, e dentre os casos arquivados, 76 eram de autoria dos Deputados, o que é por volta de 55\% das propostas de autoria dos Deputados. Até janeiro de 2018 somente 5\% dos Projetos de Lei de autoria de Deputados haviam sido transformados em Lei Ordinária, contra 70\% dos Projetos apresentados pelo Executivo. Tais dados nos levam a crer que, no uso de PL's para atuação na política externa, existe sim uma vontade crescente de participação da Câmara dos Deputados, tendo proposto 145 PL's desde o ano de 1990, e com uma tendência a alta, tal como afirmado por Figueira, mas que o protagonismo segue do Executivo, com uma taxa de aprovação consideravelmente mais alta que os demais atores. 
Tabela 1 - Proposições de Projetos de Lei Apreciadas pela CREDN de 1990 a 2017

\begin{tabular}{|c|c|c|c|c|c|c|c|c|c|c|}
\hline \multirow{2}{*}{ Autor } & \multicolumn{3}{|c|}{ Deputados } & \multicolumn{3}{|c|}{ Executivo } & \multicolumn{4}{|c|}{ Outros } \\
\hline & Quantidade & \% Tipo & $\%$ Autor & Quantidade & \% Tipo & $\%$ Autor & Quantidade & \%Tipo & $\%$ Autor & Total \\
\hline Rejeitado & \begin{tabular}{|l|}
76 \\
\end{tabular} & $85 \%$ & $55 \%$ & 8 & $9 \%$ & $20 \%$ & 5 & $6 \%$ & $33 \%$ & 89 \\
\hline Apensados a PL & 11 & $92 \%$ & $8 \%$ & 0 & $0 \%$ & $0 \%$ & 1 & $8 \%$ & $7 \%$ & 12 \\
\hline Lei Ordinária & 9 & $24 \%$ & $5 \%$ & 26 & $70 \%$ & $65 \%$ & 2 & $6 \%$ & $13 \%$ & 37 \\
\hline Retirado & 3 & $0 \%$ & $0 \%$ & 0 & $0 \%$ & $0 \%$ & 0 & $0 \%$ & $0 \%$ & 3 \\
\hline Tramitando & 46 & $78 \%$ & $32 \%$ & 6 & $10 \%$ & $15 \%$ & 7 & $12 \%$ & $47 \%$ & 59 \\
\hline Total & 145 & & & 40 & & & 15 & & & \\
\hline
\end{tabular}

Fonte: Dados compilados pela autora a partir do portal da Câmara dos Deputados, 2019.

\subsection{Do uso dos projetos de decreto legislativo}

Gráfico 2 - Proposições de Projetos de Decreto Legislativo Apreciadas pela CREDN de 1990 a 2017

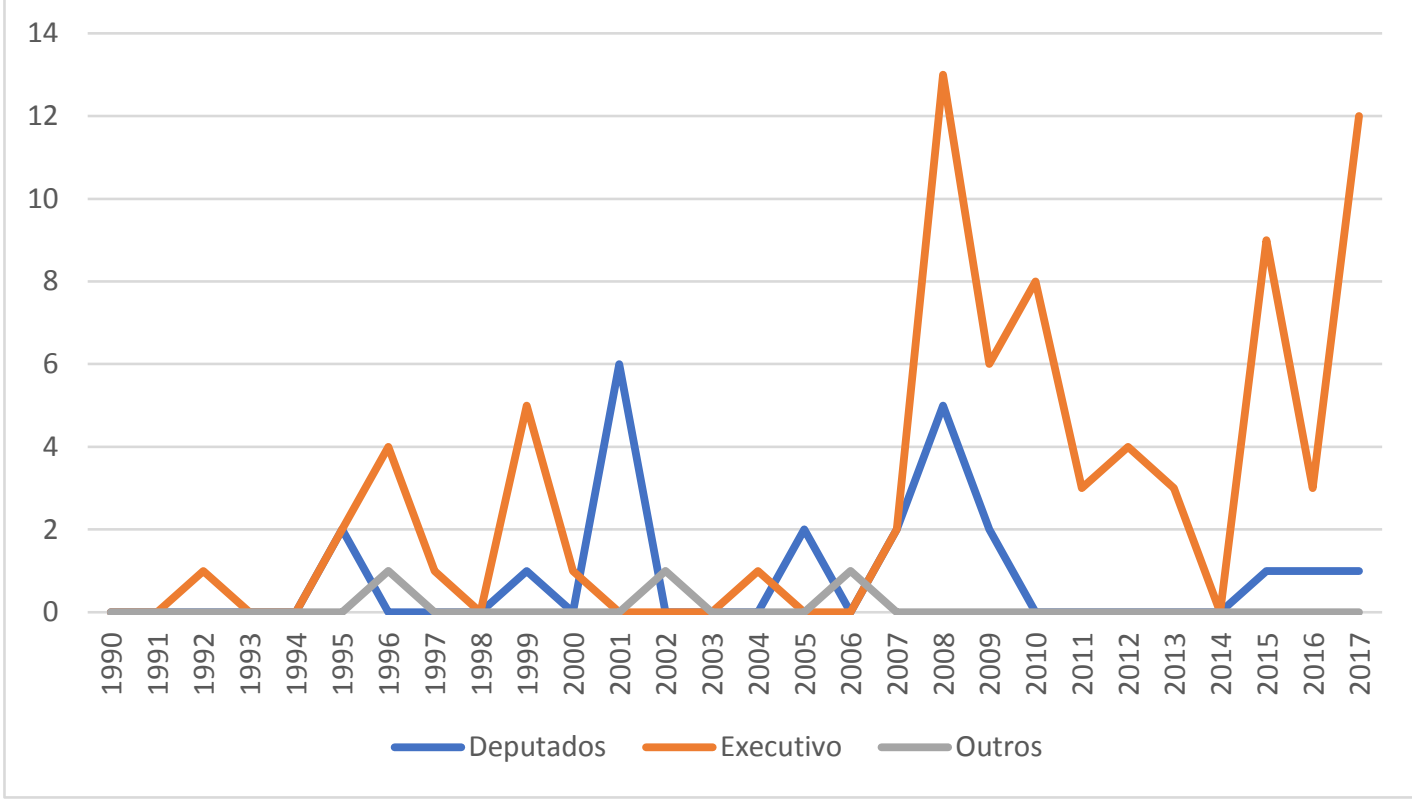

Fonte: Dados compilados pela autora a partir do portal da Câmara dos Deputados, 2019.

A análise dos Projetos de Decreto Legislativo mostrou um protagonismo do Executivo já nas proposições tramitadas. Foram 78 proposições de atos internacionais do Executivo contra apenas 23 proposições de Deputados Federais.

Sobre a atuação da Câmara, dois fatos se mostram especialmente significativos. Primeiramente, foi a existência de tentativas claras de influência ex ante, como mudanças no processo decisório da tramitação de acordos por meio de PDC's.

O PDC 8/1999, do Deputado Pedro Valadares (PSB-SE) tem em sua ementa a proposta de dispor sobre a apreciação de atos internacionais pelo Congresso Nacional. Da mesma forma, o PDC 852/2001, do Deputado Henrique Fontana (PT-RS) convoca plebiscito para decidir sobre a 
participação do Brasil na Área de Livre Comércio das Américas (ALCA). A tentativa mais clara de tentativa de atuação ex ante foi o PDC 11/2007, do Deputado Antonio Carlos Mendes Thame (PSDB-SP), que versava sobre o estabelecimento de diretrizes para a negociação de atos internacionais que regulem as obrigações brasileiras para redução de emissões de gases de efeito estufa e as ações cooperativas para enfrentar mudanças climáticas globais decorrentes da elevação da temperatura média no planeta.

Também chamou atenção a alta taxa de rejeição de propostas de Deputados neste segmento, mais alta inclusive do que em Projetos de Lei. Das 28 propostas feitas pelos membros da Câmara, 14 foram arquivadas ${ }^{9}$, cerca de $60 \%$ das propostas. Isso também significou que $74 \%$ das propostas rejeitadas vieram de Deputados. Junta-se ao fato que nenhuma proposta foi, de fato, aprovada. Dentre as propostas restantes 4 foram apensadas a outros projetos, 4 foram retiradas pelo autor, e somente $2^{10}$ ainda têm chance de serem aprovadas, aguardando relator ainda na CREDN, tendo sido apresentados só em 2016 e 2017.

Os dados permitem inferir, tal qual colocado por Diniz e Ribeiro, a existência de uma forte vontade de participação, comprovada pela presença de PDC's que visavam dar mais espaço à atuação dos Deputados, mas tais tentativas, bem como demais projetos, foram barradas.

Tabela 2 - Proposições de Projetos de Decreto Legislativo Apreciadas pela CREDN de 1990 a 2017

\begin{tabular}{r|c|c|c|c|c|c|c|c|c|c} 
Autor & \multicolumn{3}{|c|}{ Deputados } & \multicolumn{4}{c|}{ Executivo } & \multicolumn{4}{c}{ Outros } \\
\hline & Quantidade & $\%$ Tipo & $\%$ Autor & Quantidade & $\%$ Tipo & $\%$ Autor & Quantidade & $\%$ Tipo & $\%$ Autor & Total \\
\hline Rejeitado & 14 & $74 \%$ & $60 \%$ & 4 & $21 \%$ & $5 \%$ & 1 & $5 \%$ & $50 \%$ & 19 \\
\hline Apensados & 3 & $100 \%$ & $13 \%$ & 0 & $0 \%$ & $0 \%$ & 0 & $0 \%$ & $0 \%$ & 3 \\
\hline Aprovado & 0 & $0 \%$ & $0 \%$ & 55 & $100 \%$ & $70 \%$ & 0 & $0 \%$ & $0 \%$ & 55 \\
\hline Retirado & 4 & $100 \%$ & $18 \%$ & 0 & $0 \%$ & $0 \%$ & 0 & $0 \%$ & $0 \%$ & 4 \\
\hline Tramitando & 2 & $10 \%$ & $9 \%$ & 18 & $86 \%$ & $25 \%$ & 1 & $4 \%$ & $50 \%$ & 21 \\
\hline Total & 23 & & & 78 & & & 2 & &
\end{tabular}

Fonte: Dados compilados pela autora a partir do portal da Câmara dos Deputados, 2019.

\footnotetext{
${ }^{9}$ Todos os casos de propostas arquivadas têm como justificativa o uso do Art. 105 do Regimento Interno da Câmara dos Deputados, que indica que o projeto ainda estava em tramitação ao fim da Legislatura. Mesmo aqueles para os quais foi requerido o desarquivamento acabaram sendo novamente arquivados nos termos do mesmo artigo.

${ }^{10}$ O PDC 398/2016 trata susta a Portaria sem número de Portaria de 17 de maio de 2016 do Ministério das Relações Exteriores, que concede passaportes diplomáticos; O PDC 849/2017 susta a Decreto presidencial $n^{\circ}$ 9.199/17 de 21 de novembro de 2017, que regulamenta a Lei de Migração (13.445/17).
} 


\subsection{Do uso dos requerimentos e das indicações}

Gráfico 3 - Proposições de Requerimentos e Indicações Apreciadas pela CREDN de 1990 a 2017

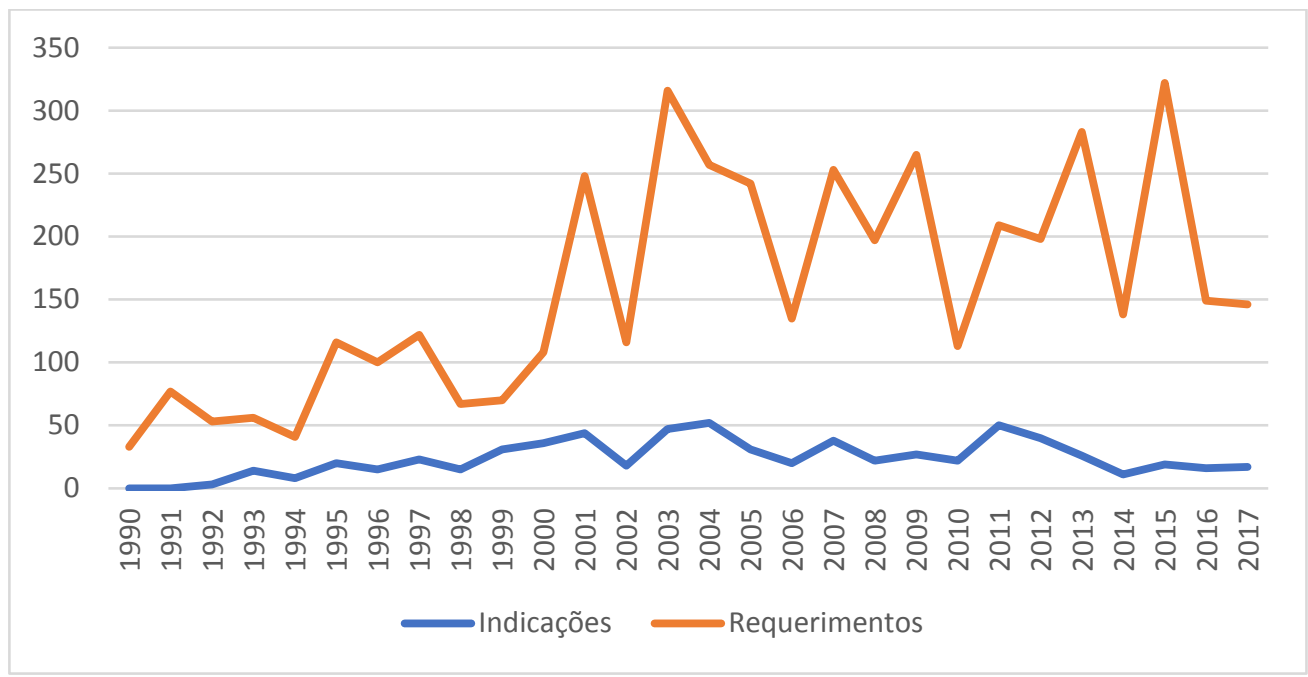

Fonte: Dados compilados pela autora a partir do portal da Câmara dos Deputados, 2019.

Por serem instrumentos de fácil tramitação, com baixíssimo custo político envolvido na utilização, já era esperado que Requerimentos e Indicações ${ }^{11}$ fossem os instrumentos mais utilizados, apesar de terem menos força legal em comparação com Projetos de Lei e Projetos de Decreto Legislativo. No caso de Requerimentos, especificamente, há uma tendência clara de alta. Foram em média 158 casos por ano de Requerimentos, contando com Requerimentos de Informação, 24 casos por ano de Indicações por parte dos Deputados.

11 Para a análise foram selecionados Requerimentos e Indicações que tivessem em sua ementa ou indexação qualquer um dos seguintes termos: "internacional"; "exterior"; "exteriores"; "exterior"; "estrangeiro" 


\subsection{Do Uso Das PEC’s De Mudança No Processo Decisório}

Gráfico 4 - PEC's Relacionadas a Política Externa Tramitadas na Câmara de 1990 a 2017

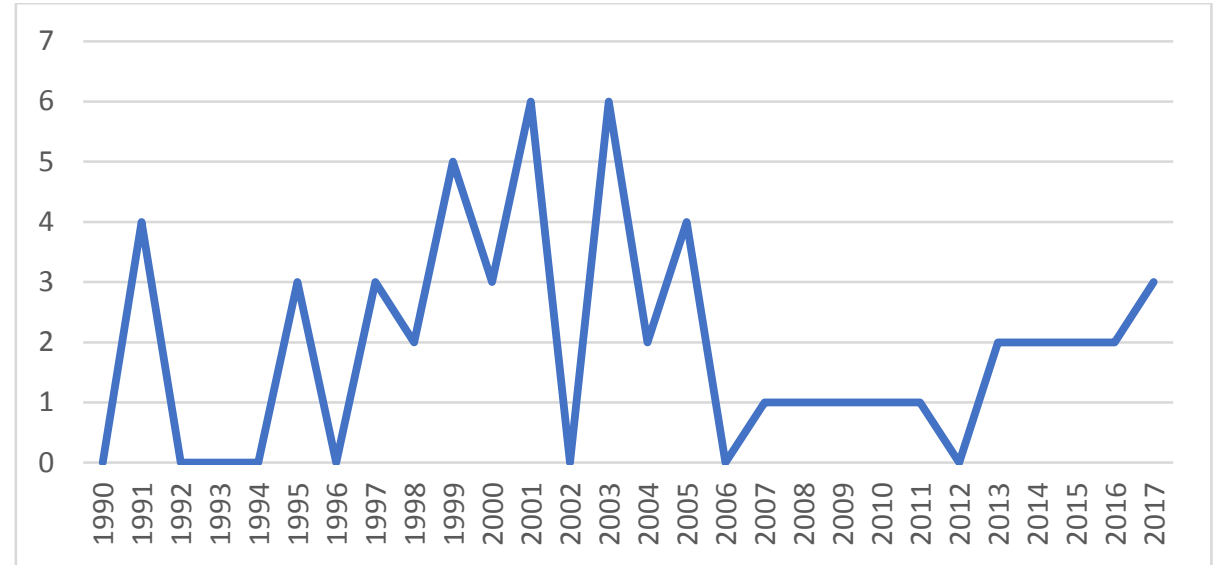

Fonte: Dados compilados pela autora a partir do portal da Câmara dos Deputados, 2019.

Entre os anos de 1990 e 2017 tramitaram na Câmara dos Deputados 54 proposições de Proposta de Emenda à Constituição que tratavam de matéria de política externa. Destas, somente 10 tratavam de mudanças no padrão decisório referente aos Atos Internacionais.

Dessas 10, somente 8 foram propostas no sentido de dar maior protagonismo à Câmara dos Deputados em matéria internacional. Isso se daria, de acordo com 3 delas, pelo estabelecimento da competência do Congresso de fazer alterações ex-post no conteúdo dos tratados, quando na tramitação no Legislativo. Outros casos seriam da (1 caso) denúncia ${ }^{12}$ do Ato Internacional, (1 caso) da escolha, feita pelo Congresso, dos negociadores para certos tipos de Acordo Internacional, e (3 casos) do estabelecimento da apreciação prévia do Congresso Nacional, quando da celebração de certos atos internacionais.

Nenhuma delas foi aprovada. As proposições feitas a partir de 2015 ainda estão em tramitação.

\footnotetext{
${ }^{12}$ Denúncia como um ato unilateral, de efeito jurídico inverso ao que produzem os instrumentos da ratificação e da adesão. Pela denúncia, um Estado manifesta sua vontade de deixar de ser parte no acordo internacional. No que tange a tratados bilaterais, a denúncia produz a extinção do próprio tratado; em relação aos multilaterais, o tratado continua a vigorar, mas sem a participação do Estado que a formula.
} 
Quadro 2 - PEC's de Mudança no Padrão Decisório Em Atos Internacionais de 1990 a 2017

\begin{tabular}{|c|c|c|}
\hline Foco No Legislativo & Tipo de Alteração & PEC's \\
\hline Sim & $\begin{array}{c}\text { Estabelecendo que o Congresso Nacional tem } \\
\text { competência para decidir sobre todos os atos } \\
\text { internacionais, e fazer alterações ex-post }\end{array}$ & $\begin{array}{c}\text { PEC 36/1999; PEC } \\
122 / 1999 ; \text { PEC } \\
402 / 2001 ;\end{array}$ \\
\hline Sim & $\begin{array}{c}\text { Estabelecendo a apreciação prévia do Congresso } \\
\text { Nacional, quando da celebração de certos atos } \\
\text { internacionais }\end{array}$ & $\begin{array}{c}\text { PEC 478/2001; PEC } \\
478 / 2001 ; \text { PEC } \\
70 / 2003\end{array}$ \\
\hline Sim & $\begin{array}{c}\text { Estabelecendo que cabe ao Congresso, após } \\
\text { arguição, a escolha de negociadores para certos } \\
\text { atos internacionais multilaterais }\end{array}$ & PEC 387/2001 \\
\hline Sim & Denúncia dos atos internacionais & PEC 75/2015 \\
\hline Não & $\begin{array}{c}\text { Estabelece que certos Atos Internacionais sejam } \\
\text { submetidos a plebiscito popular }\end{array}$ & PEC 389/2005 \\
\hline Não & $\begin{array}{c}\text { Igualando tratados internacionais de direitos } \\
\text { humanos aprovados por três quintos das duas casas } \\
\text { legislativas }\end{array}$ & PEC 257/2016 \\
\hline
\end{tabular}

Fonte: Dados compilados pela autora a partir do portal da Câmara dos Deputados, 2019.

\subsection{Do uso geral dos instrumentos}

Gráfico 5 - Uso dos Instrumentos pela Câmara dos Deputados de 1990 a 2017

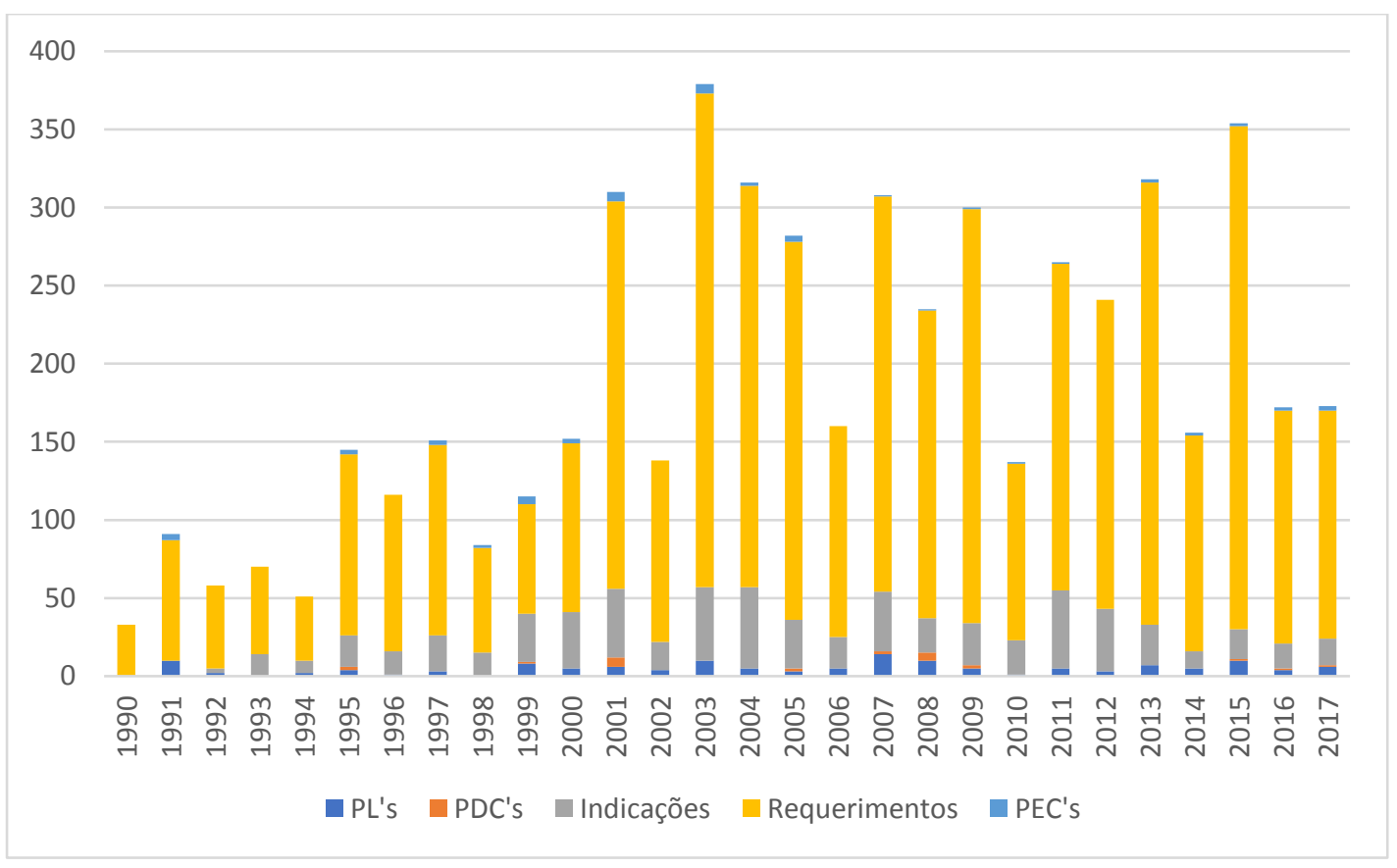

Fonte: Dados compilados pela autora a partir do portal da Câmara dos Deputados, 2019. 
No total foram 5256 proposições pela autoria de deputados nos últimos 28 anos. Em termos de comparação, desconsiderando-se Requerimentos e Indicações, que só podem ser propostos por congressistas, foram 351 proposições de Deputados Federais, em 880 casos, cerca de $40 \%$ do total. Com uma média de proposições em matéria de política externa de cerca de 200 por ano, faz-se essencial reconhecer a importância do estudo da atuação da Câmara dos Deputados, mesmo que não seja uma atuação de protagonismo.

\section{Conclusão}

Ao longo deste trabalho, foi realizado um esforço no sentido de situar a Câmara dos Deputados na configuração institucional atual. Foram descritos os instrumentos aqui considerados, bem como aspectos gerais da tramitação na Casa. A revisão da literatura existente permitiu apontar as diferentes vertentes existentes no tratamento da Política Externa quando se considera o Legislativo como ator, que aliado à análise dos dados nos levou a um campo de novas possibilidades, quando consideramos possíveis mudanças de paradigma nesta área de estudo.

A conclusão geral dos autores especializados da área é que há uma crescente participação do Legislativo nas matérias internacionais, indicada pelas vertentes que consideram uma flexibilização no que é de fato influência, e admitem influência direta e indireta além da mera aprovação dos atos ex-post. As análises aqui realizadas mostraram que é seguro afirmar que as conclusões que chegaram ainda se fazem verdadeiras nos dias de hoje, dado que são condizentes com as conclusões a que se chegaram neste estudo.

Há uma constância na utilização dos instrumentos, com momentos de alta frequentes. Assim sendo, a análise dos dados permite inferir uma crescente vontade de participação da Câmara dos Deputados na política externa, como explicitada pelos Projetos de Decreto Legislativo e pelas Propostas de Emenda à Constituição. O uso de Projetos de Lei, Requerimentos e Indicações é também constante e alto, com Requerimentos e Indicações sendo os instrumentos mais utilizados, seguidos pelos Projetos de Lei.

Apesar da análise não ter incluído mecanismos de atuação informal e indireta acreditamos que o uso dos instrumentos, como descritos neste trabalho, é um indicador forte de que há indícios suficientes de que se deve questionar o senso comum da participação do Legislativo, aqui representado pela Câmara, só como uma formalidade de chancela automática dos tratados internacionais, e de que se deve ver a Câmara como um ator ativo, que movimenta quase 200 proposições em matéria de política externa de sua autoria anualmente, e que merece ter essa atuação estudada mais a fundo.

No avanço da temática, se faria interessante estudar por que, apesar dos indicativos de desejo de maior participação na política externa por parte dos parlamentares, eles próprios barrarem as 
tentativas mudança no padrão decisório, bem como se realmente há um protagonismo de temática nos temas que eles tratariam em política externa, como por exemplo itens de agenda soft.

\section{Referências}

ABRANCHES, Sérgio. Presidencialismo de Coalizão: o dilema institucional brasileiro. Rio de Janeiro: Dados, v.31, n. 1, 1988.

ALEXANDRE, Cristina V. M., O congresso brasileiro e a política externa (1985-2005). Rio de Janeiro: EdPUC, Instituto de Relações Internacionais, 2006.

ARAUJO, Paulo Magalhães. Bicameralismo e Poder Executivo no Brasil: revisão de projetos presidenciais entre 1989-2010. Opinião Pública, Campinas, v. 20, n. 1, p. 67-95, abr. 2014.

BAENA SOARES, João C. O Processo Legislativo e a Aprovação de Acordos Internacionais Assinados pelo Brasil. Brasília: Instituto Rio Branco, 2005.

BALEEIRO, Aliomar; SOBRINHO, Barbosa L. Constituições Brasileiras, 3. ed. Brasília: Senado Federal, Subsecretaria de Edições Técnicas, 2012.5 v.

BONAVIDES, Paulo. A evolução constitucional do Brasil. Estudos Avançados. São Paulo, v. 14, n. 40, p. 155-176, dez. 2000.

BRASIL. Congresso Nacional. Atribuições do Congresso Nacional. Disponível em: http://www.congressonacional.leg.br/portal/congresso/atribuicoes. Acesso em: 28 de abril de 2016.

BRASIL. [Constituição (1988)]. Constituição Da República Federativa do Brasil de 1988. Disponível em: http://www.planalto.gov.br/ccivil_03/constituicao/ConstituicaoCompilado.htm. Acesso em: 28 abr. 2016.

CARDOSO, Evorah. Demandas do Legislativo pela condução da política externa brasileira: constituição de um novo veto player? São Paulo: USP, 2006.

CASON, Jeffrey; POWER, Timothy. Presidentialization, Pluralization, and the Rollback of Itamaraty: Explaining Change in Brazilian Foreign Policy Making in the Cardoso-Lula Era. International Political Science Review, v. 30, n. 2, p. 117-140, 2009.

DE FARIA, Carlos A. P. O Itamaraty e a política externa brasileira: do insulamento à busca de coordenação dos atores governamentais e de cooperação com os agentes societários. Rio de Janeiro: Contexto Internacional, v. 34, n. 1, p. 311-355, 2012.

DINIZ, Simone. Atos internacionais e atuação do legislativo. Teoria \& Pesquisa: Revista de Ciência Política, v. 17, n.11, p. 19-32, 2009.

DINIZ, Simone; RIBEIRO, Cláudio. O. The role of the Brazilian congress in foreign policy: an empirical contribution to the debate. Rio de Janeiro: Brazilian Political Science Review, v. 3, n. 5, p. 21-39, 2008.

FELIU, Pedro \& MIRANDA, Rosana. Congresso Nacional e Política Externa. O caso do envio de tropas ao Haiti Argentina, Brasil e Chile. Revista Política Hoje, v. 20, n. 1, p. 32-41, 2011. 
FERREIRA, Marcelo C. Congresso Nacional e política externa da integração: um controverso debate acadêmico. Ponto-e-vírgula, v. 5, n. 12, p. 202-214, 2009

FIGUEIRA, Ariane C. R. Processo Decisório em Política Externa no Brasil. São Paulo: USP, Faculdade de Filosofia, Letras e Ciências Humanas, 2009.

FIGUEIREDO, Argelina; LIMONGI, Fernando. Executivo e Legislativo na Nova República. São Paulo: EdFGV, 1999.

FIORINA, Morris P. Congress: The Keystone of Washington Establishment. New Haven: Yale Press, 1989.

GALDINO, Manoel; OLIVEIRA, Amâncio J. S. N.; RIBEIRO, Pedro F. Política externa chilena e espectro ideológico político-partidário: um estudo sobre a Câmara dos Deputados 2002-2006). Rio de Janeiro: Dados, v. 52, n. 4, p. 835-870, 2010.

GERRING, J. Mere Description. British Journal of Political Science, n. 42, p. 721-746, 2010.

LIMA, Maria R. S.; SANTOS, Fabiano. O Congresso e a Política de Comércio Exterior. Lua Nova, n. 52, p.121-149, 2001.

LIMA, Maria R. S. Instituições Democráticas e Política Exterior. Contexto Internacional, v. 22, n. 2, p.31-47, 2000.

LIMONGI, Fernando. A democracia no Brasil: presidencialismo, coalizão partidária e processo decisório. Novos Estudos, São Paulo, n. 76, p. 17-41, nov. 2006.

LIMONGI, Fernando. Da Teoria da Modernização ao Novo Institucionalismo. São Paulo: Universidade de São Paulo, 2002.

LINDSAY, J. Congress and Foreign Policy: Why the Hill Matters. Political Science Quarterly, v. 107, n. 4, p. 607-628, 1993.

MARCH, James G.; OLSEN, Johan, P. The New Institutionalism: Organizational Factors in Political Life. The American Political Science Review, v. 78, n. 3, p. 734-749, 1984.

MARTIN, Lisa. Democratic Commitments: legislatures and international cooperation. Princeton University Press, 2000.

MCDONNELL, Robert M. Explaining the Determinants of Foreign Policy Voting Behaviour in the Brazilian Houses of Legislature, with a Focus on the Senate. São Paulo: EdUSP, 2016.

MENDONÇA, Christopher B. O Congresso Nacional e a Política Externa. In: SEMINÁRIO NACIONAL DE PÓS-GRADUAÇÃO EM RELAÇÕES INTERNACIONAIS, 1., Brasília. 2012.

MILANI, Carlos R. S. \& PINHEIRO; Letícia. A Política Externa Brasileira e Os Desafios De Sua Caracterização Como Política Pública. Rio de Janeiro: Contexto Internacional, v. 35, n. 1, p. 11-41, 2013.

MONTESQUIEU. O Espírito das Leis. São Paulo: Martin Claret, 2010.

MORAIS, Thais. O Debate Em Torno Do Sistema Político Brasileiro: Análises, Polêmicas E Desafios. Revista Inter-Legere, v. 3, n. 5, p. 21-37, 2009. 
NEVES, João de C. O Congresso Nacional e a política externa brasileira. In: ALTEMANI, Henrique; LESSA, Antônio Carlos (org.). Relações internacionais do Brasil: temas e agendas. São Paulo: Editora Saraiva, 2006, p. 43-61. v. 2.

NICOLAU, Jairo M. Eleições no Brasil: do Império aos dias atuais. Rio de Janeiro: Zahar, 2012.

NICOLAU, Jairo M. Sistemas Eleitorais. 5.ed. rev. e atual. Rio de Janeiro: Editora FGV, 2004.

OLIVEIRA, Amâncio J. Partidos políticos e política externa: o comportamento legislativo na Câmara de Deputados, 1995-2009. São Paulo: Centro de Estudos das Negociações Internacionais, 2013.

OLIVEIRA, Rodrigo R. O Congresso Nacional e a Política Externa Brasileira. Posicionamento dos senadores frente às negociações para a formação da ALCA (1994-2005). Brasília: EdUnB, 2011.

PINHEIRO, Letícia; SALOMÓN, Mónica. Análise de Política Externa e Política Externa Brasileira: trajetória, desafios e possibilidades de um campo de estudos. Revista Brasileira de Política Internacional, v. 56, n. 1, p. 40-59, 2013.

POLETTI, Ronaldo. Constituições Brasileiras, 3. ed. Brasília: Senado Federal, Subsecretaria de Edições Técnicas, 2012.v. 3.

PORTO, Walter C. Constituições Brasileiras, 3. ed. Brasília: Senado Federal, Subsecretaria de Edições Técnicas, 2012. v. 3

PUTNAM, Robert D. Diplomacia e política doméstica: a lógica dos jogos de dois níveis. Revista de Sociologia Política, Curitiba, v. 18, n. 36, p. 147-174, 2010

SCHIMIDT, Stefanie T. Política Externa e o Poder Legislativo: um olhar sobre a Comissão de Relações Exteriores e Defesa Nacional do Senado Federal. São Paulo: USP, 2011.

TÁCITO, Caio. Constituições Brasileiras, 3. ed. Brasília: Senado Federal, Subsecretaria de Edições Técnicas, 2012. v. 3

TSEBELIS, George. Processo Decisório em Sistemas Políticos: veto players no presidencialismo, parlamentarismo, multicameralismo e pluripartidarismo. Revista Brasileira de Ciências Sociais, n. 34. p. 48-71, 1997.

WEINGAST, Barry R. Congress, Regulation and the Decline of Nuclear Power. Public Policy, n. 22, p.23-47, 1980.

Artigo submetido em: 2020-01-30

Reapresentado em: 2020-04-30

Aceito em: 2020-05-11 